\title{
Evaluation of Front Line Demonstration of Cassava (Manihot esculenta Crantz) in Ernakulam District of Kerala, India
}

\author{
Vijendra Kumar Meena*, Shinoj Subramanian, Shoji Joy Edtion, \\ N.V. Dipti, K. Simta and Pushp Raj Anjlo
}

\author{
Krishi Vigyan Kendra, ICAR- Central Marine Fisheries Research Institute, \\ Narakkal, Kochi, Kerala, India \\ *Corresponding author
}

\begin{tabular}{|c|c|}
\hline & A B S T R A C T \\
\hline $\begin{array}{l}\text { Ke y w o r d s } \\
\text { Cassava, Front Line } \\
\text { Demonstration } \\
\text { (FLDS), Variety. }\end{array}$ & $\begin{array}{l}\text { To popularize Cassava (Manihot esculenta Crantz.) among the farmers of Ernakulum } \\
\text { district of Kerala, a front line demonstration organized by Krishi Vigyan Kendra, } \\
\text { ICAR- Central Marine Fisheries Research Institute on } 10 \text { selected farmer's field } \\
\text { during } 2010-11 \text {. For this purpose, two cultivars of Cassava i.e. "Sree vijay" and "local } \\
\text { variety" were used and the demonstration was conducted during the kharif season of } \\
\text { (May to September). The results of demonstration revealed that Sree vijay and local }\end{array}$ \\
\hline Article Info & variety produced 250 and $150 \mathrm{q} / \mathrm{ha}$, respectively. The average income of Sree vijay \\
\hline $\begin{array}{l}\text { Accepted: } \\
\text { 25 January } 2017 \\
\text { Available Online: } \\
\text { 10 February } 2017 \\
\end{array}$ & $\begin{array}{l}\text { vijay and local cultivar were Rs. } 175000 \text { and } 1.42 \text { and } 90000 \text { and } 1.66 \text {, respectively. } \\
\text { farmer's field has the potential for in knowledge of the farmer as well as showed high } \\
\text { level at satisfaction about technology. }\end{array}$ \\
\hline
\end{tabular}

\section{Introduction}

Cassava (Manihot esculenta C.), popularly known as Tapioca which was introduced into India by the Portuguese during the $17^{\text {th }}$ century as a food crop, now the crop gradually changing its role as an industrial raw material (Lakshmi et al., 2000). The importance of cassava as a food crop was well recognized in Kerala, south India during the $20^{\text {th }}$ century, when famine struck in India at the time of the Second World War. The crop integrated well with the traditions and culture of Kerala. Adaptability to poor soils, and easy to establish in high as well as low rainfall areas, with low relative resistance to pests and diseases problem are important charters with attract the cultivation of that helped to anchor cassava they are in some area. Cassava was used as substitute to rice especially by the poor peoples. Now a day's changing economic conditions and improved living standard in food habit of the people, it has become an important dish even for the richer sections of the society. About $70 \%$ of the total cassava production is used as food either directly or in processed form.

'Parboiled chips' is a method of processing cassava tuber for storage. These chips are harder than the lain sundried chips due to the partial gelatinization (Lakshmi et al., 2000). 
'Sago 'is an important food product derived from cassava starch.

Local varieties of this crop mature in a period of 10-11 months and also having low yield potentials. The long duration and poor yield potential lower it yield per unit time of the crop. Under such scenario required an introduction of short-duration varieties of about 7 months duration can be harvested with high tonnage. Local cultivar can produce 20-25 t/ha in 10-11 months. Frontline demonstration (FLDS) is the new concept of field demonstration of new technology evolved by the Indian council of agriculture research (ICAR) with main objective of demonstrate newly released crop production technologies and its management practices with the farmer, under different agro climatic region of the country (Choudhary et al.,1999). While demonstrating the technologies in the farmer's field by the scientist need to required study the factors which contributing for crop production. To popularizations of technology among the FLDS has play crucial role for farmer's perspective. The main objective of the experiment was making the technology more beneficiaries for farmer's community and also improved the production level without adding many inputs. Keeping, all the fact in mind present study to appraised the yield level of cassava for beneficiaries and for enhancing its productivity and popularity among the farmers.

\section{Materials and Methods}

The demonstrations were conducted on the field of 10 selected farmer's Ernakulum district of Kerala under the supervision of Krishi Vigyan Kendra during kharif (month of May to September) season of 2010-11(One Years). Field was selected from different villages of Ernakulum district viz Mooknoor, Evadanakad, Chari, Kuzplli Aymphilly
Angamali and Prembhuoor, Ernakulum, Kothamagalam, Penchant etc. Each farmer kept 1 ha area for front line demonstration. Before conducting FLDs, farmer group meeting was held and skill training was imparted to the selected farmers regarding different aspect of front line demonstration and cultivation practices developed by ICARCTCRI Choudhary, (1999). To popularize the scientific cassava cultivation technology, first of all constrains in cassava production though participatory approach preferential ranking technique (Meena et al., 2015). We was utilized to identify the constraints faced by the responded to participating farmers in Cassava cultivation.

The package of practices was consisting of improved varieties, seed treatment, maintenance of optimum plant stand, and recommended fertilizer dose proper time method of harvesting. The spacing followed was at $0.75 \mathrm{~m} \times 0.75 \mathrm{~m}$ in improved variety and local variety with rate of $2000-2500$ stem cutting $/ \mathrm{ha}^{-1}$. During 2010-11 Sree vijay (CTCRI) variety was used. Sree vijay varieties were short duration and matured in 210 days (7 months), whereas varieties which farmers cultivate the district required 10-12 months.

The entire participating farmer was trained on all accepted of Cassava production system. To study the impact of front line demonstration, out of total 50 farmers a sample of 10 farmers was selected as respondent through proportionate sampling. Production and economic data for FLDs and local practices were collected and analyzed as per the methodology suggested by Meena et al., 2015. The extension gap, technology gap and technology index were calculated using the formula Kumar, 2014a).

Extension gap $\left(\mathrm{qha}^{1}\right)=$ Demonstration yield $\left(q a^{1}\right)$ - yield of local check $\left(\mathrm{qha}^{1}\right)$ 
Technology gap $\left(\mathrm{qha}^{1}\right)=$ Potential yield $\left(\mathrm{qha}^{1}\right)$ - Demonstration yield ( $\left.\mathrm{qha}^{1}\right)$

Technology index (\%) =Potential yield $\left(\mathrm{qha}^{1}\right)$ - Demonstration yield/ Potential yield $\mathrm{x} 100$

\section{Results and Discussion}

\section{Constraints in cassava production}

At the Farmer's field Cassava cultivation problems were documented. Preferential ranking scientific technique was utilized to identify the constraints faced by the respondent participating farmer in Cassava production. The ranking were given by the different farmers are given in (Table 1). A perusal of table indicated that lack of suitable high yielding variety (HYVs) $(85.00 \%)$ was given the top most rank followed by low technical knowledge $(80.00 \%)$. Other constraint such low or erratic rainfall, labour cost high, post harvest management were found to reduce Cassava production. Among all the constraints, low soil fertility got least concerns. Similar constraints were observed in maize by Dhaka et al., 2010; Meena et al., 2015, in rice by Meena et al., 2015a in pigeon pea by Sreelakshmi et al., 2012 and in mustard by Katare et al., 2007 in different agro climatic conditions.

\section{Performance of FLD}

A comparison of productivity levels between demonstrated varieties and local crop variety were given in Table 2. It was observed that productivity of Cassava in Ernakulum district under improved production technologies was $250 \mathrm{q} / \mathrm{ha}$ and while it was only $150 \mathrm{q} / \mathrm{ha}$ in case of local variety (Table 2). The technology index of Sree vijay was $78.57 \%$ higher, than local cultivars yield of the front line demonstration trial and potential yield of the different varieties of crop was compared to estimate the yield gaps which were further categorized into technology index. The technology gap showed that gap in the demonstration yield over potential yield was 350q/ ha. Technology index show the feasibility of the variety at the farmer's field. The lower the value of technology index more is the feasibility. Table 2 revealed that the technology index value were 78.57 per cent. Similar improved yield were observed in maize (Dhaka et al., 2010; Meena et al., 2015), in rice (Meena et al., 2015a), in pigeon pea (Sreelakshmi et al., 2012) in wheat (Kumar, 2014a), in chickpea (Kumar, 2014b), in onion (Hiremath et al., 2007) and in mustard (Katare et al., 2007), in moong (Kumar, 2013) under different agro climatic conditions.

The extension gap showed in varieties $75 \mathrm{qha}^{-1}$. The technology gap 275 $\mathrm{qha}^{-1}$ during the experimentation emphasizes the need to educate the farmers through several of improved agricultural production technologies. The technology gap observed might be attributing to the dissimilarity in soil fertility status and whether condition. Identification and use of farming situation, specific intervention may have more implication in enhancing system productivity (Katare et al., 2011). The technology index showed the feasibility of the evolved technology at the farmer field. The technology indexes of variety $\left(78.57 \mathrm{qha}^{-1}\right)$ during the study period may be attributed to the difference in soil fertility status, weather condition. Similar improved yield were observed in maize (Dhaka et al., 2010), rice (Meena et al., 2015 b) pigeon pea (Sreelakshmi et al., 2012), wheat (Kumar, R. 2014a), chickpea (Kumar, 2014 b) onion (Hiremath et al., 2007) and in mustard (Katare et al., 2007), (Kumar, 2013) Yard long bean (Meena et al., 2016) in different agro climatic conditions. 
Table.1 Ranks given by farmers for different constraints $(n=50)$

\begin{tabular}{|l|l|l|l|}
\hline S. No. & Constraints & Percentage & Ranks \\
\hline 1 & Lack of suitable HYV & 85.00 & I \\
\hline 2 & Labour problem & 80.00 & II \\
\hline 3 & Low soil fertility & 40.00 & VII \\
\hline 4 & Marketing & 50.00 & IV \\
\hline 5 & Low technical knowledge & 65.00 & III \\
\hline 6 & Wild animals & 45.10 & V \\
\hline
\end{tabular}

Table.2 Yield of Cassava crop as influenced by improved production technologies and high yielding varieties over local practices in farmer's field

\begin{tabular}{|c|c|c|c|c|c|c|c|c|c|c|c|}
\hline \multirow[t]{2}{*}{ Year } & \multirow[t]{2}{*}{ Variety } & \multirow{2}{*}{$\begin{array}{l}\text { Area } \\
\text { ha }\end{array}$} & \multirow{2}{*}{\begin{tabular}{|l} 
Demo. \\
No
\end{tabular}} & \multirow{2}{*}{$\begin{array}{l}\text { Potential } \\
\text { Yield } \\
\left(\text { qha }^{-1}\right)\end{array}$} & \multicolumn{4}{|c|}{ Yield $\left(\right.$ qha $\left.^{-1}\right)$ improved technology } & \multirow{2}{*}{$\begin{array}{l}\text { Extension } \\
\operatorname{gap}_{\left(\text {qha }^{-1}\right)}\end{array}$} & \multirow{2}{*}{$\begin{array}{l}\text { Technology } \\
\text { gap } \\
\left(\text { qha }^{-1}\right)\end{array}$} & \multirow{2}{*}{$\begin{array}{l}\text { Technology } \\
\text { index }(\%)\end{array}$} \\
\hline & & & & & Max. & Min. & Avg. & Local & & & \\
\hline $\begin{array}{l}2010- \\
11 \\
\end{array}$ & $\begin{array}{l}\text { Sree } \\
\text { Vijay }\end{array}$ & 10 & 10 & 350 & 250 & 200 & 225 & 150 & 75 & 275 & 78.57 \\
\hline
\end{tabular}

Table.3 Economics of cassava crop as affected by improved production technology over local practice

\begin{tabular}{|c|c|c|c|c|c|c|c|c|c|c|c|}
\hline \multirow{2}{*}{ Year } & \multirow{2}{*}{ Variety } & \multicolumn{2}{|c|}{$\begin{array}{l}\text { Total cost of cultivation } \\
\left(\text { Rs.ha }^{-1}\right)\end{array}$} & \multicolumn{2}{|c|}{ Gross return(Rs.ha $\left.{ }^{-1}\right)$} & \multicolumn{2}{|c|}{ Gross return(Rs.ha $\left.{ }^{-1}\right)$} & \multicolumn{2}{|c|}{ Benefit: cost ratio } & \multirow{2}{*}{$\begin{array}{l}\text { Additional } \\
\text { cost of } \\
\text { cultivation } \\
\left(\text { Rs.ha }^{-1}\right) \\
\end{array}$} & \multirow{2}{*}{$\begin{array}{l}\text { Additional } \\
\text { Net of } \\
\text { Cultivation } \\
\left(\text { Rs.ha }^{-1}\right)\end{array}$} \\
\hline & & $\begin{array}{c}\text { Improved } \\
\text { technologies }\end{array}$ & $\begin{array}{c}\text { Local } \\
\text { technologies }\end{array}$ & $\begin{array}{l}\text { Improved } \\
\text { technologies }\end{array}$ & $\begin{array}{c}\text { Local } \\
\text { technologies }\end{array}$ & $\begin{array}{c}\text { Improved } \\
\text { technologies }\end{array}$ & $\begin{array}{c}\text { Local } \\
\text { technologies }\end{array}$ & $\begin{array}{l}\text { Improved } \\
\text { technologies }\end{array}$ & $\begin{array}{c}\text { Local } \\
\text { technologies }\end{array}$ & & \\
\hline $\begin{array}{c}2010- \\
11\end{array}$ & $\begin{array}{l}\text { Sree } \\
\text { Viiay }\end{array}$ & 750000 & 60000 & 250000 & 150000 & 175000 & 90000 & 1.42 & 1.66 & 100000 & 85000 \\
\hline
\end{tabular}


The economic feasibility of improved technology over traditional Farmers practices was calculated depending on the prevailing prices of inputs and output cost (Table 3). It was found that during one year of study with cassava variety the cost of production of Cassava variety Sree vijay was Rs. 75000 ha. $^{-1}$ In case of local variety cost of production was Rs 60000 in one years of study. The additional cost incurred in the improved technology might be mainly due to cost involved in the purchase of improved seed. improved variety in Front line demonstration recorded higher gross returns in improved variety (Rs.250000 $\mathrm{ha}^{-1}$ ) and local variety (Rs.150000 $\mathrm{ha}^{-1}$ ) and Net return improved variety (Rs.175000 $\mathrm{ha}^{-1}$ ) while lower in case of local variety (Rs.90000 ha ${ }^{-1}$ ) the higher benefit cost ratio were recorded variety (1.42) in produced local variety (1.66).

On the basis of above discussed the present study can be conclude that the yield gap between conventional practices and improved production technology was perceptibly higher and there is urgent need to make stronger extension services for educating farmers for implementation of improved production technology. Precipitin input used by farmers wise improved technology result they got better productivity present time and used input. However, the yield level under FLDs was better than the local varieties and performance of these varieties could be further improved by adopting recommended production technology. Hence, it can be observed that increased yield was due to adoption of high yielding varieties and condition frontline demonstration of proven technology. This will subsequently increase the income as well as the livelihood of the farming community. From the above research finding it can be also conclude that the maximum number of the respondents had medium level of knowledge and extent of adoption regarding recommended cassava production technology. The study reported lack of suitable HYV as major constraint by the beneficiaries and is ranked first followed by low technical knowledge.

\section{References}

Choudhary, B.N. 1999. Krishi Vigyan Kendra- A guide for KVK managers. Division of Agricultural Extension, ICAR, pp. 73-78.

Dhaka, B.L., Meena, B.S. and Suwalka, R.L. 2010. Popularization of improved maize production technology through frontline demonstration in south eastern Rajasthan. J. Agri. Sci., 1(1): 39-42.

Hiremath, S.M., Nagaraju, M.V. 2007. Shashidhar K.K. Impact of front line demonstrations on onion productivity in farmer's field. Paper presented In: Nation Seminar on Appropriate Extension Strategies Management Rural Resources, University Agriculture Sciences, Dharwad, 18-20, p.100.

Katare, Subhas, S.K., Pandey and Mohd. Mustafa Yield gap analysis of rapeseedmustard through front line demonstration. Agriculture Update, 5-7.

Kumar, R. 2014. Crop technology demonstration: an effective communication approach for dissemination of wheat production technology. Agri. Sci. Digest, 34(2): 131-134.

Kumar, R. 2014 b. Assessment of technology gap and productivity gain through Crop technology demonstration in chickpea. Indian J. Agri. Res., 48(2): 162-164.

Kumar, R. 2013. Evaluation of Crop technology demonstration of mustard crop in Transitional plain of Inland Drainage Zone of Rajasthan. Int. J. Agri. Stat. Sci., 9(2): 657-660.

Lakshmi, K.R., T. Srinivas and V.S. Santhosh Mithra. 2000. Long Term Trends in Production of Tuber Crops. Technical 
Bulletin Series 32, Central Tuber Crops Research Institute, Thiruvananthapuram, pp. 14-17.

Meena, V.K., Edison, S.N.V., Dipti, K. 2016. Simta on farm testing: An effective way of transfer of technology of yard long bean [Vigna unguiculata ssp. sesquipedalis (L.) Verde.] in Ernakulam district of Kerala, India. Agric. Sci. Digest., 36(2): 126-129.

Meena, V.K., Edison, S. and Subramani, S. 2015b. Frontline demonstration an effective way of popularization of system of rice intensification (SRI).
Agri. Sci. Digest, 35(3): 215-217.

Meena, V.K., Subramannian, S., Anjlo, P. and Dipti, N.V. 2015a. Populerization of maize among the small farmers of Ernakulam district of Kerala through front line demonstration. Indian J. Agri. Res., 49(6): 558-561.

Sreelakshmi, C.H., Sameer Kumar, C.V. and Shivani, D. 2012. Productivity enhancement of pigeon pea (Cajanus cajan L.) through improved production technology. Madras Agri. J., 99(4-6): $248-250$.

\section{How to cite this article:}

Vijendra Kumar Meena, Shinoj Subramanian, Shoji Joy Edtion, N.V. Dipti, K. Simta and Pushp Raj Anjlo. 2017. Evaluation of Front Line Demonstration of Cassava (Manihot esculenta Crantz) in Ernakulam District of Kerala. Int.J.Curr.Microbiol.App.Sci. 6(2): 1818-1823. doi: http://dx.doi.org/10.20546/ijcmas.2017.602.204 